\title{
Evaluation the Level of Hepcidin and Iron Homeostasis in Sera of Pregnant Women with Anemia in Samarra City
}

\author{
Hanan Nayef Mohammed ${ }^{1}$, Rafah Razooq Hameed Al-Samarrai \\ ${ }^{1}$ Post Graduate, ${ }^{2}$ Prof., Department of Chemistry, College of Education, University of Samarra, Salah al-Din/Iraq
}

\begin{abstract}
Cross sectional study was carried out to evaluate the level of hepcidin in sera of pregnant women with anemia. The study include 86 sample from women with reproductive age(18-35)year. Forty six sample collected from pregnant women with anemia and forty sample from healthy pregnant women as control group in $2^{\text {nd }}$ and $3^{\text {rd }}$ trimester, all samples were collected from Healthy center and Specialized Clinics in Samarra for the period from 14 December 2018 to 22 January 2019.

The study include the determination of Packed cell volume (P.C.V) ratiohemoglobin-Hb conc., Total Iron, total iron binding capacity-TIBC conc., Transferrin conc., Hepcidin conc., Total protein -TP conc., Albumin conc, Globulin conc., The activity of liver enzymes (Alanine aminotransferase-ALT, aspartate aminotransferase-AST and Alkaline phosphatase-ALP), the results showed thatthe levels of PCV ratio, $\mathrm{Hb}$, total iron and hepciden significant decreased $\mathrm{p} \leq 0.05$ in pregnant women with anemia as compared with control group, with significant $\mathrm{p} \leq 0.05$ increase in level of TIBC, Transferrin, and the activity of AST and ALP in pregnant women with anemia as compared with control group, with no significant change $\mathrm{p} \leq 0.05$ to the level of total protein, albumin, globulin and the activity of ALT in pregnant women with anemia as compared with control group.
\end{abstract}

Keywords: Hepcidin, anemic pregnant women, total iron, Transferrin, liver enzymes.

\section{Introduction}

Pregnancy or gestation, is the period which one or more fetal develop inside the mother's womb, In which the unborn baby spends about 38-40 weeks in the uterus. It's not an illness, but it's a stressful condition in which manyphysiological and metabolic functions are altered to aconsiderable extent ${ }^{(1,2)}$. Many medical problems were increase during pregnancy due to complex interplay between lifestyle and demographic factors. This medical proplems include gestational diabete, venous thromboembolism, hypertension and anemia ${ }^{(3)}$.

Anemia is common in pregnancy, and it's a risk

\section{Corresponding Author:}

\section{Rafah Razooq Hameed Al-Samarrai}

Prof., Department of Chemistry, College of Education, University of Smarra, Salah al-Din/Iraq e-mail: rafah_alsamarrai@uosamarra.edu.iq factor for infant low birth weight and iron deficiency anemia, as well as deem as one of the main risk factors for take part in $20-40 \%$ of mother deaths directly or indirectly through. preeclampsia, cardiac.failure, preeclampsia, puerperal sepsis, antepartum haemorrhage and postpartum haemorrhage ${ }^{(4,5)}$.

Mostly, anemia in pregnancy is caused to reduction of iron deficiency or folic acid deficiency or both. Folate and Iron supplementation is fixed during pregnancy to block the complications. The hemoglobin concentration in normal pregnancy, becomes diluted according to the elevate the volume of circulating blood ${ }^{(6,5)}$. The regulation of iron metabolism is done by Hepcidin ${ }^{(7)}$.

Hepcidin, is a peptide hormones (composed of 25 amino acids), Its a main regulator of iron metabolism ${ }^{(7)}$. It is mainly synthesized in the liver. The mechanism of the regulations for the iron metabolism is done by the inhibition the absorption of iron in the duodenum by acting mobilization of liver iron $\operatorname{Slack}^{(8,9)}$. 
The aim of the present study is to evaluate the level of hepcidin and iron homeostasis in sera of pregnant women with anemia in Samarra city.

\section{Materials and Method}

Study Design: Cross sectional study was carried out to 86 samples from pregnant womenwith reproductive age(18-35)year, Forty six sample collected from pregnant women with anemia as patients group and forty sample from healthy pregnant women as control group in $2^{\text {nd }}$ and $3^{\text {rd }}$ trimester, all samples were collected from Specialized Clinics and Healthy center in Samarra cityfor the period from 14 December 2018 to 22 January 2019.

Method: The study include determination of blood hemoglobin- $\mathrm{Hb}$ concentration, packed cell volumePCV and also determination the concentration of serum hepcidin, total iron, total iron binding capacityTIBC, transferrin, Transferrin saturation,total protein, albumin and liver enzymes(aspartate aminotransferase -AST, Alanine aminotransferase-ALT, and Alkaline phosphatase -ALP) activity according to the standard method.

Statistical Analysis: The results were analyzed using the Statistical Package for the Social SciencesSPSS using the Completely randomized design-CRD method through a t-test to analyze the variance between two groups and at a probability level $(\mathrm{P} \leq 0.05)$ and with this analysis, the simple linear

\section{Results}

The present study include determination of blood $\mathrm{Hb}$ concentration, PCV ratio and hepcidin, total iron, TIBC, transferrin, Transferrin saturation,total protein,albumin, globulin concentration in sera of anemic pregnant women as patient group and pregnant women without anemia as control group.

The results indicate that the Mean \pm SD of Hepcidin were $5.878 \pm 1.699 \mathrm{ng} / \mathrm{ml}$ in sera of pregnat women with anemia as patient group and $8.260 \pm 1.912 \mathrm{ng} / \mathrm{ml}$ in sera of pregnant women without anemia as control group, table 1 .

Table 1: Mean \pm SD of hepcidin, Hb, PCV, total iron, TIBC, transferrin, Transferrin saturation, total protein, albumin, globulin concentration in patients and control groups

\begin{tabular}{|l|c|c|c|}
\hline \multirow{2}{*}{ Parameters } & \multicolumn{2}{|c|}{ Mean \pm S.D } & \multirow{2}{*}{ P $\leq$} \\
\cline { 2 - 3 } & Control & Patients & 0.05 \\
\hline Hepcidin $(\mathrm{ng} / \mathrm{ml})$ & $8.260 \pm 1.912$ & $5.878 \pm 1.699$ & 0.05 \\
\hline P.C.V $(\%)$ & $38.55 \pm 1.205$ & $34.021 \pm 1.939$ & 0.05 \\
\hline $\mathrm{Hb}(\mathrm{g} / \mathrm{dl})$ & $12.5402 \pm 0.436$ & $10.99 \pm 0.627$ & 0.05 \\
\hline Iron $(\mu \mathrm{mol} / \mathrm{L})$ & $36.788 \pm 7.086$ & $16.611 \pm 3.479$ & 0.05 \\
\hline T.I.B.C $(\mu \mathrm{mol} / \mathrm{L})$ & $77.83 \pm 13.213$ & $92.373 \pm 14.708$ & 0.05 \\
\hline Transferrin saturation $(\%)$ & $49.463 \pm 16.906$ & $18.906 \pm 6.827$ & 0.05 \\
\hline Transferrin $(\mu \mathrm{mol} / \mathrm{L})$ & $54.235 \pm 9.237$ & $65.433 \pm 10.061$ & \\
\hline
\end{tabular}

Table 1 also showed that the Mean \pm SD of PCV ratio were $34.021 \pm 1.939 \%$ in blood of patient group and $38.55 \pm 1.205 \%$ in blood of control group, while the concentration of $\mathrm{Hb} 10.99 \pm 0.627 \mathrm{~g} / \mathrm{dl}$ in blood of patient group and $38.55 \pm 1.205$ in control group. The total iron concentration were $16.611 \pm 3.479 \mu \mathrm{mol} / \mathrm{L}$ in sera of patient group and $12.5402 \pm 0.436 \mu \mathrm{mol} / \mathrm{L}$ in control group, also the concentration of TIBC were $92.373 \pm 14.708 \mu \mathrm{mol}$ in patient group and $77.83 \pm$ $13.213 \mu \mathrm{mol} / \mathrm{L}$ in control group. The ratio of Transferrin saturation were $18.906 \pm 6.827 \%$ and $49.463 \pm 16.906 \%$ in pateints and cotrol group respecrivley. As well as the concentration of transferrin were $65.433 \pm 10.061$ $\mu \mathrm{mol} / \mathrm{L}$ and $54.235 \pm 9.237$ in pateints and cotrol group respecrivley.

The results obtained from Table 1 indicate that the level of Hepcidin,PCV,Hemglobin, total iron, Transferrin saturation were significantly decreased at $p \leq 0.05$ in sera of pregnat women with anemia as 
comparing with pregnant women without anemia as control group. While the level of TIBC and Transferrin were significantly increased at $\mathrm{p} \leq 0.05$ in sera of patients group as copmare with control group.
Table 2 showed the Mean $\pm \mathrm{SD}$ of total protein, albumin and globulin concentration in sera of patient and control groups.

Table 2: Mean \pm SD of serum total protein, albumin and globulin concentration in patient and control groups.

\begin{tabular}{|l|c|c|c|}
\hline \multirow{2}{*}{ Parameters } & \multicolumn{2}{|c|}{ Mean \pm S.D } & \multirow{2}{*}{ P $\leq$} \\
\cline { 2 - 3 } & Control & Patients & N.S* \\
\hline T.P. $(\mathrm{g} / \mathrm{dl})$ & $6.188 \pm 0.586$ & $6.329 \pm 0.684$ & N.S \\
\hline Albumin $(\mathrm{g} / \mathrm{dl})$ & $4.430 \pm 0.627$ & $4.012 \pm 0.780$ & N.S \\
\hline Globulin $(\mathrm{g} / \mathrm{d} \mathrm{l})$ & $1.794 \pm 0.954$ & $2.255 \pm 1.134$ & \\
\hline
\end{tabular}

$*$ N.S. $=$ Non-significant

Table 2 showed that the Mean \pm SD for total protein concetration were $6.329 \pm 0.684 \mathrm{~g} / \mathrm{dl}$ in patient group and $6.188 \pm 0.586 \mathrm{~g} / \mathrm{dl}$ in control group, while the concentration of albumin were $4.012 \pm 0.780 \mathrm{~g} / \mathrm{dl}$ in patient group and $4.430 \pm 0.627 \mathrm{~g} / \mathrm{dl}$ in control group. The concentration of globulin were $2.255 \pm 1.134 \mathrm{~g} / \mathrm{dl}$ and $1.794 \pm 0.954 \mathrm{~g} / \mathrm{dl}$ in pateints and cotrol group respecrivley.

Table 2 showed that no significant difference at $\mathrm{p} \leq 0.05$ between patients and conrol group about the concentration of total protein, albumin and globulin.
The activity of liver enzymes were included in this study, the results indicate that the Mean \pm SD of ALP activity were $9.929 \pm 1.555 \mathrm{U} / \mathrm{L}$ and $7.257 \pm 2.210 \mathrm{U} / \mathrm{L}$ 237 in pateints and cotrol group respecrivley, and 5.561 $\pm 2.712 \mathrm{U} / \mathrm{L}$ in sear of patient group for ALT activity as comparing with $6.968 \pm 4.853 \mathrm{U} / \mathrm{L}$ as control group. While the activity of AST were $7.936 \pm 2.401 \mathrm{U} / \mathrm{L}$ in patints group and $10.553 \pm 2.483 \mathrm{U} / \mathrm{L}$ in control group, Table 3.

Table 3: Mean \pm SD of serum liver enzymes in patient and control groups.

\begin{tabular}{|l|c|c|c|}
\hline \multirow{2}{*}{ Parameters } & \multicolumn{2}{|c|}{ Mean \pm S.D } & \multirow{2}{*}{ P $\leq$} \\
\cline { 2 - 4 } & Control & $9.929 \pm 1.555$ & 0.05 \\
\hline ALP(U/L) & $7.257 \pm 2.210$ & $5.561 \pm 2.712$ & N.S* \\
\hline ALT (U/L) & $6.968 \pm 4.853$ & $7.936 \pm 2.401$ & 0.05 \\
\hline
\end{tabular}

*N.S. $=$ Non-significant

The results obtained from table 3 showed that the activity of ALP were significantly increased at $p \leq 0.05$ in sera of pregnat women with anemia as coparing with pregnant women without anemia as control group, while the AST was significantly at $\mathrm{p} \leq 0.05$ decreased in sera of patient group, with no significant variation for ALT between patients and control group.

\section{Discussion}

In pregnancy the concentration of hepcidin significantly reducing gradually from the $1 \mathrm{st}$, to the 2nd and 3rd trimesters and reach undetectable levels, The level of hormone correlate with iron parameters during pregnancy ${ }^{(10)}$, in which hepcidin able to provide. Maximal bioavailability. of iron for fetus and mother ${ }^{(11)}$. 
The results of the present study was agree with finding of Manolov et al ${ }^{(11)}$, which indicate that the level of hepcidine significantly decreased in sera of pregnant women with anemia as compered with pregnant women without anemia and pregnant women with anemia of chronic inflammation. This study conclude that the decrease and increase in serum hepcidin concentration provides a backbone for choosing the right therapeutic process in the treatment of anemia in pregnancy, Hepcidin able to provide. maximal bioavailability. of iron for fetus and mother,Because its plays an important role in regulation the concentration of iron in human body via release of iron from macrophages and repression of iron absorption from intestine ${ }^{(12)}$.

Wahed et $a l^{(13)}$, found that the serum total iron significantly elevated in second and third trimester of pregnant women which take iron supplemente as compared with same category of women were not take iron supplemt, other wise the TIBC also increased in groups of anemic pregnant women who take iron supplemente, or rich diet with iron.

The results of the present study were agree with the finding of Zaidan ${ }^{(14)}$, which found that the level of Total iron, $\mathrm{Hb}$ and $\mathrm{PCV}$ were signficantly decreased, while the result of total protein, albumin and globulin significantly elevated in anemic pregnant women, this finding were disagrrment with the finding of the present study, and the results of liver enzymes was agree with finding of the present study about ALT(but not AST), Which found that AST and ALT dont effect during anemic pregnant women but ALP was increased in $60 \%$ of samples for this study .

Form all the results we can conclude that the iron deficiency reduced the level of hepcidine in anemic pregnant women.

Ethical Clearance: The Research Ethical Committee at scientific research by ethical approval of both MOH and MOHSER in Iraq.

\section{Conflict of Interest: Non}

Funding: Self-funding

\section{References}

1. Obrowski S, Obrowski M, Starski K. Normal Pregnancy: A Clinical Review. Acad J Ped Neonatol. 2016; 1(1): 555554.

2. Quanungo S, Mukherjea M. Ontogenic profile of some antioxidants and lipid per-oxidation in human placental and fetal tissues. Mol Cell Biochem. 2000;1-2:11-19.

3. Knight M, Tuffnell D, Kenyon S et al . Saving lives, improving mothers' care: surveillance of maternal deaths in the UK 2011-13 and lessons learned to inform maternity care from the UK and Ireland Confidential Enquiries into Maternal Deaths and Morbidity 2009-13 . Oxford : University of Oxford, 2015 .

4 Harrison KA. Severity of anemia and operative mortality and morbidity. Lancet 2004; 1:1392-3.

5. Satyam, P. and Khushbu, Y. Maternal Anemia in Pregnancy: An Overview. Ijppr.Human, 2015; Vol. 4 (3): 164-179.

6. Shiro, k.Approaches to Anemia in Pregnancy ${ }^{e e}$, JMAJ 2009; 52(4): 214-218

7. Roy CN, Andrews NC. Anemia of inflammation: the hepcidin link. Curr Opin Hematol. 2005;12:107111.

8. Kroot JJ, Kemna EH, Bansal SS, Busbridge M, Campostrini N, Girelli D et al. Results of the first international round robin for the quantification of urinary and plasma hepcidin assays: need for standardization. Haematologica 2009;94:1748-52

9. Ramey G, Deschemin JC, Durel B. Hepcidin targets ferroportin for degradation in hepatocytes. Haematologica 2010; 95:501-504.

10. Van Santen S, Kroot JJ, Zijderveld G, Wiegerinck ET, Spaanderman ME, Swinkels DW. The iron regulatory hormone hepcidin is decreased in pregnancy: a prospective longitudinal study. Clin Chem Lab Med. 2013 Jul;51(7):1395-401.

11. Manolov, V.; Marinov, B.; Velizarova, M. et al . Anemia in pregnancy and serum hepcidin levels. Inter. J. Adv. Res. 2015; 3(1): 758-761.

12. Fleming $M$. The regulation of hepcidin and its effects on systemic and cellular iron metabolism. Hematology American Society Hematology Education Program; 2008; 151-158.

13. Wahed F, Latif SA, Uddin MM, Mahamud MM, Sarker D, Hossain MZ. Persistence of low serum iron and high total iron binding capacity in pregnant women. Mymensingh Med J. 2007;16(2):132-136.

14. Zaidan, N.K. Iron Deficiency Anemia With Liver Functions During Pregnancy. Journal of university of Anbar for Pure science2013;6(1):100-104. 